\title{
Efforts into Legal Protection Against The Children Exploitation as Beggars
}

\author{
Devi Rahayu ${ }^{1}$ \\ $\left\{\right.$ rahayudevi78@yahoo.com $\left.{ }^{1}\right\}$ \\ ${ }^{1}$ University of Trunojoyo Madura, Jl. Raya Telang, Telang, Bangkalan, Kamal, PerumahanTelangInda, \\ Telang, Kamal, Madura, JawaTimur 69162, Indonesia
}

\begin{abstract}
Madurese people are well known as hard workers. The reality, however, does not represent it. It is indicated by one of the communities in Pamekasan and Sumenep regencies. Most of the inhabitants' profession is a beggar who is practiced from generation to generation. Being a beggar is the worst type of jobs for children because it devastates infants psychologically and exploits them as well. They have the same rights to grow both physically and mentally and to meet their fundamental rights. This essay aims to analyze the background of the given profession and the local government's roles to address the issue under discussion. The research used empirical methods, with a factual approach, and descriptive qualitative designs to analyze the selected data. The economic background is not the only contributing factor why they beg, but also the descent profession does. When their parent succeeded in the given job, then they occupy the position later. Being a beggar in a labor law context is the worst job for children because it is a children exploitation. This is the local government's obligation to guarantee to provide the children's rights and to protect them from exploitation. Through the Kyai(religious priest) extension, the government has socialized the children's rights and the importance of education and thus strongly encouraged them to enroll in Madrasah (Islamic elementary school). Furthermore, livestock is offered but seemed to be ineffective. The government also builds the parents, children, and societies' awareness to meet the legal protection of children achieved.
\end{abstract}

Keywords: Child Exploitation, Child Rights, Legal Protection, Madurese People

\section{Introduction}

Children have the inborn rights to grow physically, mentally, and socially. Indonesia introduces the guarantee of legal protection into children and minimizes the potential impacts of children labor mandated in law No 20 the year 1999 about the minimum ages of labor, law No 1 the year 2000 about the abuse and the removal of the worse jobs for children, and law No 23 the year 2002 in relation to children protection.

In nature, they are prohibited from working because they should spend their time to study, play, and have fun, chances, and facilities to achieve their dreams. However, reality represents that they have engaged in economic activities as children labor. Law No 13 the year 2003 about the labor law which certifies protection to children in terms of children's rights protections.

Madurese people are well known to be hard workers. However, contrasting reality can be seen where the people beg. The inhabitants in some parts of Pamekasan and Sumenep regencies are a beggar as to credited as a "beggar" village. Firstly, the economic background is the primary reason for occupying the profession. Since the profession benefits them, they can afford a house and meet their daily basic needs. Then, being a beggar subsequently becomes a profession. The practice has been through from generation to generation. The parents inviting 
their children to beg will increase their income. Being a beggar is the worse job for children seen from law labor and children exploitation.

Local government must guarantee the children's rights and protect them from exploitation. Working with Kyai, the government has socialized the children's rights, particularly in the academic field and has strongly recommended them to enroll in an Islamic elementary school (Madrasah). Livestock has been offered as well but appears to be unhelpful. The government also raises the parents, children, and societies' awareness about legal protection in terms of the fulfillment of children's rights. The significant issues studied in this investigation contain what the contributing factors of children become a beggar and look at the roles of local government in finding solutions to the social problems and protect them legally who become a beggar.

\section{Methodology}

This is empirical law research since it tries to analyze and describes the treatment to the exploited children in Madura regencies. This research applies the factual approach, investigating children exploitation phenomena as beggar found in Madura and offering solutions to the sought answers of the begging phenomenon, finding the reasons why they beg and studying the government policies addressing the issues being studied.

The research was undertaken in Pamekasan regency, including Branta and Panglegur villages, Tlanakan district, and Sumenep regency, covering PragaanDaya village, Pragaan district. We chose the given settings due to the number of the inhabitants who have profession as beggars are high enough. Informants who are selected mainly focused on the children begging, parents, local authorities (head of the village), political leaders, and stakeholders. Snowball sampling is a research technique used in selecting the informants; finding the relevant informants based on the previous information given by the previous informants.

The techniques of data collection consist of an interview and distributing a questionnaire dealing with primary data. Secondary data collection involves library research. The researcher analyzed the data qualitatively and subsequently described them to reveal the contributing factors of why they beg, offer solutions to children exploitation, and reinforce the law to children exploitation who beg.

\section{Findings}

\section{1. Children as Labourer}

The expression of child labors suggests a condition in which they are shackled with a kind of work under very varied conditions. They do in a long series, ongoing activities and do not know when to end. Perhaps, at one end, the work will be useful to improve or accelerate their physical, mental, social, and moral development as a child. While the other ends, it will rob and destroy their lives as children, the term "destructive and exploitative." In these two poles, the various fields of work with their vast activities are cultivated by child laborers[1].

According to the ILO (International Labor Organization), the meaning of child labor is: "Children who lost their childhood and future, prematurely leading adult lives, working long hours for low wages under conditions damaging their health and physical and mental development."

The definition contains the "keywords" of children losing their childhood and future (to which they are entitled), doing adult work, long hours, low pay, working conditions that endanger the health and physical and mental development. ILO distinguishes between light 
work and hazardous work. Children who work in light work are allowed while dangerous working children are prohibited.

Laboring children represents today's world, particularly in developing countries. This is mainly due to the slow movement addressing the children as laborers happening in this century. It is easily understood because the skepticism and argumentation develop in society, for instance: (a) the education does not meet the need of children with disadvantaged economic and even send them away from their environment, (b) children with low economic background are required to help their parents to meet families' daily need, (c) in individual factories, the children's roles are expected to increase their product competitiveness, (d) the law enforcement of children labourer is downward impossible to apply due to the vast number of children working in that factories, (e) common knowledge states that government has no right to get involved in how parents treat their children[2].

The working children phenomenon is increasing in Indonesia. There are three types of labor children[3]: first, they partly help their parents as they deal with daily normality, such as working in the field in a particular season. It is called as child worker where the parents allow their children to study and play still in limited space, second, they work in factories, farming, and other areas belong to factories to meet the families' bread or even become the primary source of family income. This type is called as child labor, and mostly they have no enough time to study and play since their schedules are conflicting, third, children work in streets such as beggars, street musicians, and ragpickers and this context, there is no direct association with a particular factory. Sociologically, they name them street children.

\subsection{Legal Protection of Child Labour}

Children need protection for the condition of objects based on physical and psychic. Children have a small body and weak. The soul of the child is vulnerable to various influences. Also, there is the fact that children often become victims in various criminal acts, such as torture, rape, murder, and others.

Child Protection law as: "(1) in the broadest sense are all rules of life that provide protection to the immature and allows them to develop, and (2) in a narrow sense as a legal protection contained in the provisions of civil law, criminal law provisions, and provisions of procedural law "[4].

Studying about child protection, there are at least two related aspects. The first aspect is related to the legislation policy governing the protection of children. On the other hand, the second aspect is related to the implementation of the policy of the legislation. Regarding the first aspect, to date has sufficient legislation to regulate the rights concerning child protection. The second aspect is whether the availability of various sets of legislation on the rights of the child has in itself attempts to realize the rights of the child and the abolition of child abuse abuses and neglect of the child's rights as may be terminated[5].

In-Law Number 23 the Year 2002 regarding Child Protection, the child refers to a person who is not yet 18 (eighteen) years of age, including a child still in the womb. Furthermore, Law Number 23 the Year 2002 on Child Protection, referred to by a child is a person who is not yet 18 (eighteen) years of age, including a child who is still in the womb. The rights of the child need to be protected so that the child can have the fullest opportunity to grow and develop properly, physically, spiritually and socially as outlined in Law Number 4 the Year 1979 regarding Child Welfare Article 2, Article 4, Article 5, Article 8 as follows. The child shall be entitled to the welfare, care, upbringing, and guidance based on compassion both in his family and in particular care to grow and develop Article 2 paragraph (1) correctly. The child shall have the right to service to develop his or her capacity and social life in accordance 
with the culture and personality of the nation, to be a good and useful citizen (Article 2 paragraph (2) a child who has no parent shall be entitled to the care of the state or person (Article 4 paragraph 1) The child who is unable to have the right to obtain assistance so that within his or her family environment can grow and develop properly (Article 5 paragraph 1) Help and service, aiming to bring prosperity to the rights of every child without distinction of sex, religion, political stance, and social standing (Article 8).

In Law No.13 of 2003 about Labour Act, legal protection on child labor is related to wages and welfare of child laborers as stated in the provisions of Article 68 to Article 75. The provisions of Article 68 determine that employers are prohibited from employing children. The philosophy of the prohibition of children from working or employing children is closely linked to protecting the rights of children, which is also guaranteed to be protected under Law no. 39 of 1999 on Human Rights. Provisions prohibiting the employment of children as outlined in the provisions of Article 68 of the Manpower Law, in line with the provisions of Article 52 paragraph (1) of Law no. 39 of 1999 on Human Rights, which provides that every child is entitled to protection by parents, family, community, and country. Furthermore, in paragraph (2) regulates the right of the child as a human right and for the benefit of the child's right, it is recognized and protected by law even since in the womb. Therefore, the philosophical prohibition of employing children is solely intended to provide a guarantee of the legal protection of the child for the sake of the development of his dignity and prestige in order to prepare for his future.

Article 68 of the Labour Act regulates the exclusion for children aged between 13-15 years to perform light work so long as it does not interfere with the development and physical, mental and social health. Employers who impose a child on light work must meet the requirements: written permission from a parent or guardian; employment agreement between employer and parent or guardian; maximum working time of three hours; done during the day and does not interfere with school time; occupational Health and Safety; a transparent working relationship; and receive wages in accordance with applicable provisions.

Article 71 paragraph (2) of the Labour Act that employers or institutions that employ children shall be eligible: under the direct supervision of a parent or guardian; working time of three hours a day; and the conditions and working environment do not interfere with physical, mental, social, and school-time development.

In addition, under article 74 of the Labour Act any person is prohibited from employing and involving children in the worst works, including any work related to slavery or the like; any work that exploits, provides or offers children for prostitution, pornographic production, pornographic performances, or gambling; any work that utilizes, provides or involves a child for the production and trade of liquor, narcotics, psychotropic substances and other addictive substances; and / or all work that endangers the health, safety or morals of the child. In this context, a child who is used by his or her parents to become a beggar is an act of hiring a child that can damage a child's moral.

\subsection{Children as a Beggar}

Children classified as street children such as a beggar should have more attention because they spend most of their life in the street. It means that they are too risky to any negative impacts of their environment that might bring which are unhealthy to their mental, physical, and social development. Their future career is also unexceptional. Children with this type of psychologically believe that they do not have to work hard to achieve something. What they do need is just hoping what people would give to them. Those are such transferred education from their parents. Indeed, this psychological state leads to be lazy. In the context of a 
community of PragaanDaya, Pragaan district, Sumenep regency, they firmly believe that "it is better to be a beggar than a thef." In their perception, begging is legal, but stealing is illegal. Since begging has become tradition, the parents pass it from generation to generation. Research indicates that the given practice in PragaanDaya has started from before the Indonesia independent (1930-1940) until the present. It remains applicable since it has enough supports from family and their surroundings. Even the disadvantaged economic condition leading them to beg, but the economic reason is not the primary concern about their practice. Accordingly, when the beggar turns to rich, they keep begging. They enjoy their profession because it is more fruitful and makes more money compared to sell or to make a fortune in timber as previously done. In other words, begging has fully nothing to do with low economic income, but mental and moral outrages are closely related. Based on the social department in Sumenep, 91 people in PragaanDaya are beggars, and they invite their children to do the same.

On the one hand, there are three villages in Pamekasan in which several beggars is high: Panglegur, LaranganTokol, danBrantahTenggi. In general, 174 people identified as beggars. The total number of an identified beggar in Pamekasan: Panglegur (69), Larangan Tokol (60), Brantah Tenggi (45), totaly are 174.

No data found in the Regional Office of Manpower and transmigration DepartmentofPamekasan demonstrating the number of child labor. However, most beggars are going to invite their children to work as they do. Surprisingly, they will "rent" a child from their neighbor if they do not have a child. This aims to increase people's empathy for their benefit.

Most of the invited children to beg ranged from five to twelve years old. When they are teenaged boy, some feel ashamed and stop begging, and some continuously do until they get married. The reason why parents threat them in this way simply because children, in the parents' perspective, belong to them as they have rights to lead children to be a beggar. They beg daily since they only go to afternoon school in Islamic boarding schools. It should be noted that begging activities are not only done in Pamekasan, but also Surabaya, Jakarta, and Kalimantan. Working in the following areas is well organized. If they do, it must be sure that they do neither attend the formal nor religious education.

The beggar is an occupation, based on the men's perspective in the three given regions. This is because their lands are saturated; they are uneducated and are unskilled. The average daily income reaches up to fifty (50) thousand and even more significant on Friday. Motivated by having more income, the parents invite their children. So far, both parents and children lack knowledge of those children must not work (as a beggar). However, the most important thing is that their children are under their parents' control, and they raise money.

The phenomenon above is against the law No 23 the year 2002 about children protection. Children have rights to play, have protection from their parents, and take education. Most of them lose their childhood period and are exploited by their or other parents for any economic advantages. Since the children are used to begging, not work hard on the other areas, they believe that begging supports them financially. The idea will be well accommodated in their mind and applied later when they grow and have children.

\subsection{Actions Taken by Local Government}

The local authorities, Regional Office of Manpower and Transmigration Department provide livestock to pet, basic need, and fund. The actions, however, are going to be ineffective because due to the provision of livestock is sold. According to Budi Setiawan (the office of the department), begging is a kind of profession, and their mental state is to beg. It makes any efforts fruitless. For that reason, the official cooperates with Kyaiand political 
leaders of the villages to cut the link of the beggar by providing relevant information towards the disengagement of begging practices to their children. They initiate to provide children education in Islamic Boarding School for free. Indeed, the social department is in charge financially during their study period. It is expected that children will later comprehend that in Islamic perspective, giving is better than taking. The children thus did not work as their parents do.

The development should start from the bottom, active participation from society both local administrative levels such as neighborhood committees, village voice, or community-based organization, handcraft community and religious affiliation activities for instance [6]. The use of media mentioned before is beneficial not only to socialize the children crisis in begging term but also is helpful to build a positive paradigm in Madurese context. Kai is considered to be an agent of change in this regards as to be useful to address the issue at hand. Most of the children attend the afternoon school in Islamic boarding schools. Therefore, we can take advantage of the roles of Kyai to educate their rights and their parents' obligation to protect their children.

Concrete actions other than building people's awareness are also required. The family empowerment enables active participation from society which bases communities such as Islamic boarding schools and religious forum[7]. The economic empowerment in the three villages with Kyai shelp can mediate the comprehension and skills to families. Involving religious institution to address the social problems can be useful since Madurese people tend to have a secure emotional attachment to Kyaiand Islamic religion so that children exploitation can be minimized.

The Regional Office of Manpower and Transmigration Department, Pamekasan Regency, has initiated to solve the problems by cooperating with Kai and the head of villages to persuade the beggars to send their children to Islamic boarding schools. They would not come along with their parents while begging, and proper education is subsequently accessible for them. The stakeholders also show a strong commitment to providing practical skills and the supported devices for family empowerment purposes and adequate supervision by KTSK in each district.

\section{Conclusion}

Children become beggar because their parents do. They believe that they will have a better income when children take apart in the activity because the presence of the children touches people's heart to give. Also, children belong to their parents. The chosen data did not represent the concrete number of children who beg.

Regarding the local government policies, parents are the targeted agenda. The designed programs such as skill development, funding, and parental socialization strongly encourage parents not to invite children working with them but send them to school instead. Madrasah (Islamic elementary school) plays a significant role in passing the agenda. The legal protection to children as a beggar has not been optimal because the existing programs are parents' economic growth-oriented. However, the better the parents' income, the better their life would be indicated by the low participation of the children work with their parents to beg. Therefore, community-based organization, developing families' capacities with Kyaiinterference employed. 


\section{References}

[1] P. Jain and R. Singhai, "A Study About Violation of Human Rights of Child Labour in India,” Int. J. Sci. Res., vol. 6, no. 3, 2017.

[2] G. A. MacDonald, "Wealth, Justice, and The Medieval Poor Law," in John Ruskin's Politics and Natural Law, Cham: Palgrave Macmillan, 2018.

[3] H. S. Banu and A. Venkatachalam, "Study on Problems of Working Children in Unorganized Sector," Paripex - Indian J. Res., vol. 6, no. 11, 2017.

[4] H. Dubowitz, "Child Sexual Abuse, and Exploitation - A Global Glimpse," Child Abus. Negl., vol. 66, 2017.

[5] J. Lewis and A. West, "Early Childhood Education and Care in England under Austerity: Continuity or Change in Political Ideas, Policy Goals, Availability, Affordability, and Quality in Childcare Market?," J. Soc. Policy, vol. 46, no. 2, 2017.

[6] J. W. Budd and et. al, "Learning About Democracy At Work: Cross-National Evidence on Individual Employee Voice Influencing Political Participation in Civil Society," ILR Rev., vol. 71, no. 4, 2017.

[7] J. Kim and J. Bryan, "The First Step to A Conceptual Framework of Parent Empowerment and Academic Performance in A National Sample," J. Couns. Dev., vol. 95 , no. 2, 2017. 